\title{
Turkey-United States' Bilateral Ties: a Tale of Convergence and Divergence of Interests
}

\author{
* Dr. Murad Ali, Assistant Professor (Corresponding Author)
}

\begin{abstract}
The paper explores bilateral ties between Turkey and the United States (US) following the end of World War II to the recent era of Trump-Erdogan. Due to its immense geostrategic significance and a strong military, throughout the Cold War period and also in the post-Cold War era, Tukey has mostly remained a key US ally. The methodology adopted for this study is based on both qualitative data available in the form of policy documents and existing literature about the subject as well as utilizing quantitative data comprising US economic and military aid and arms' sales to Turkey obtained from databases of United States Agency for International Development (USAID) and Stockholm International Peace Research Institute (SIPRI) respectively. Like numerous developing countries in other parts of the world, Turkey also became one of the biggest recipients of US economic and military assistance and Washington also provided huge arms to Ankara during the Cold War years. The US has provided Turkey an aggregate of US\$ 70 billion in civilian and military assistance and has delivered its arms worth US\$ 34 billion. However, it has not been a smooth journey as their bilateral relationship experienced some upheavals not only during the Cold War period but ties have been strained by various thorny matters in recent years. These include Turkey's dispute with Greece on Cyprus, targeting Kurdish fighters in Syria, purchase of S-400 defense systems from Russia, and human rights violations at home. By examining these vital points of concern, the paper concludes that although both countries have historically maintained warm bilateral ties, several divergent issues have marred the relationship between the two countries in recent years.
\end{abstract}

Keywords: $\quad$ Turkey, US, bilateral ties, aid, NATO, Cold War

\section{Introduction}

Historically, Turkey has mostly remained a key US ally. Outside Europe, it was the only nation that received US aid under the Marshall Plan aimed for the reconstruction of war-battered European countries. Under the Marshall Plan, eponymously named after George Marshall, former US Secretary of State, Turkey was provided US\$ 137 million from 1948 to 1952 (Bacik \& Aras, 2004; Brooks, 2006). During this period, the 1950 Korean War also played a key role in bringing Turkey and the US closer as the former sent about 4,500 military personnel under the command of the US (Isyar, 2005; Vander Lippe, 2000). Regarding the strength of military mission in terms of troops, Ankara provided the fourth-largest number of soldiers following the US, Britain, and Canada (Brown, 2008; Robins, 2003). Because of Turkey's significant support in this overseas military mission under the US command, the latter fully endorsed Ankara's membership to join the North Atlantic Treaty Organisation (NATO). Consequently, Turkey became an important member of NATO in 1952 (Avci, 2005; Isyar, 2005). Gunter (2005) asserts that on account of these reasons, US strategists and policymakers started to view Turkey in high esteem because being a secular democratic Islamic country, Turkey offered an essential example for other Muslim states in the geo-strategically imperative Middle Eastern region. It has been appropriately pointed out that unlike Israel or Greece, Turkey did not have any domestic constituency in Washington to lobby for it but despite that, it emerged a key country in the Cold War theatre due to its geo-strategic location as it was situated at the fulcrum of three distinctive regions comprising Asia, Europe and the Middle East (Athanassopoulou, 2001).

During the Cold War period as well as during the two Iraq wars and in the US-led war on terror, Turkey sided with its western allies and reaped the dividend in the form of US economic and military aid as well as getting access to US defense arsenals. According to data obtained from United States Agency for International Development (USAID), from 1948 to 2008, the US provided a total of US\$ 30 billion in economic aid and over US\$ 40 billion in security assistance (USAID, 2015). Similarly, according to Stockholm International Peace Research Institute (SIPRI), Turkey has

* Department of Political Science, University of Malakand, Chakdara, Pakistan Email: muradali.uom@gmail.com 
purchased military arms worth US\$ 57 billion from 1950 to 2019, out of which the US alone has delivered Turkey arms worth about US\$ 34 billion (SIPRI, 2020). It is more than half of the amount that Turkey has purchased from all other countries together. These figures indicate the significance of Turkey for successive US administrations and policymakers. However, it is not to be implied that the relations between the two countries have always remained cordial. Due to divergence of interests on some foreign policy matters, for example on the Cyprus dispute which is discussed in the next section, the bilateral relationship between the two allies faded which also affected US foreign aid policy towards Turkey in the 1970s. Due to this, there are also striking ups and downs in US aid and military sales to Turkey. For instance from the years 1974 to 1978, Washington delivered meager civilian and security cooperation and significantly reduced the provision of military hardware to Ankara because of an escalating political temperature between Turkey and Greece on the Cyprus dispute. It shows that because of security, political and geostrategic compulsions, the US is always prepared to provide and suspend non-security and security assistance and sales of arms. The remaining of the paper examines these ups and downs in the relations between the two countries. After discussing the Cyprus issue and how it affected bilateral ties between Washington and Ankara, the paper unpacks that how the regime change in Tehran and the marching of Soviet forces to Kabul rekindled the Washington-Ankara bonhomie. The subsequent sections highlight the changing nature of relations between the two countries from the Gulf wars and the war on terror to their recent disenchantment on account of multiple thorny issues.

\section{Cyprus Issue and the US Reaction: a Dent in the Alliance}

While the US-Turkey relationship mostly had a smooth trajectory during most of the Cold War era, it was severely strained by the Cyprus issue and subsequent escalation of Turley's tensions with Greece. This particular dispute has a considerable resemblance with the issue of Kashmir which the British left unresolved at the time of partition of the Indo-subcontinent in 1947. The Cyprus issue has remained an apple of discord between two NATO members, Turkey and Greece for a long time, specifically since following the rising tensions between them in the mid-1960s. Nevertheless, as Henze (1993) argues, in contrast to the Kashmir dispute between New Delhi and Islamabad who have fought several wars over this matter, there has been no direct military confrontation between Turkey and Greece on the controversy over Cyprus. It is relevant to explore the history of the dispute and how it affected bilateral ties between Washington and Ankara. Following the end of the British reign, on $16^{\text {th }}$ August 1960, Cyprus proclaimed independence. At the time of independence, it comprised of two main ethnicities: Turkish Cypriots and Greek Cypriots. However, the situation was far from normal. Tensions between the two ethnicities reached to a new level with the eruption of the intercommunal violence on $21^{\text {st }}$ December, 1963 (Bolukbasi, 1993). The intercommunal hostilities claimed the lives of scores of Turkish Cypriots. In the unabated tension between the two communities, Turkey was mulling over a military intervention to prevent the Greek Cypriots from inflicting further harm on Turkish Cypriots (Bolukbasi, 1993). But on $5^{\text {th }}$ June 1964, US President Johnson wrote a letter to Turkish Prime Minister Inonu in which Ankara was asked not to execute its military's plan of entering into Cyprus. Thus, the letter was aimed at dissuading and preventing Turkey from military intervention in Cyprus which significantly affected the contours of the US-Turkey relationship. The letter from the US president specified that the involvement of Turkish security forces could result in a direct conflict between Greece and Turkey, both of which belonged to the NATO alliance (Bolukbasi, 1993). Besides, the despatch from the US president also maintained that if Ankara's military action caused a direct involvement of the Soviet forces on behalf of Cyprus because Makarios, the first president of Cyprus had developed close ties with the Soviet leadership, in that case, NATO would have no obligation to side with Turkey (Bolukbasi, 1993; Robins, 2003). Thus, the US had two main concerns. One, it wanted to prevent a direct military confrontation between Turkey and Greece as both were NATO allies. Second, the US was keenly observing the gestures between the leadership of Cyprus and his Soviet counterpart in the backdrop of the Cold War and was apprehensive that the Soviets could intervene in the dispute to support Makarios against Turkey. The letter from the US leader came as a severe blow to the Turkish nation and it generated an unprecedented uproar among Turkish people regarding the trustworthiness of the US as a partner (Ahmad, 2003; Gunter, 2005). The country witnessed "anti-American demonstrations by Turkish students" on university campuses and in several cities (Davison, 1988, p. 12). In the same context, it has been argued that the letter from then US President was received with a stern reaction from Ankara as it was widely felt by Turkish people 
that Washington was having a firm control in policymaking in Ankara and that now the US started openly to dictate foreign relations and foreign policy of Turkey at this critical juncture (Bolukbasi, 1993). In view of these developments, the Turkish Premier also stated in an interview that "if our allies do not change their attitude, the Western Alliance will break up... a new kind of world will then come into being on a new pattern, and in this new world Turkey will find herself a place" (Bolukbasi, 1993, p. 516). With these words, Turkish political leadership also showed no hesitation to issue veiled threats to the US-led Western alliance that Ankara would pursue its interests irrespective of its implications for the US-Turkey alliance. Hence, although the two countries were close allies and NATO members, their relationship weakened considerably on account of the US response during the Cyprus crisis.

However, after 11 long years of intermittent ethnic violence and subsequent volatility in Cyprus and particularly following the coup of July 1974, which was staged "by the Greek junta" and carried out by nationalists belonging to Greek Cypriots and Greek security personnel (Bolukbasi, 1993, p. 505), Turkish military had no option but to enter the island. Ankara's military involvement in Cyprus led to the splitting up of the island between Turkish Cypriots and Greek Cypriots. These events created a gulf in the US-Turkey bilateral relationship particularly when the former enforced an arms embargo on the latter which stayed effective from 1975 to 1978 (Brooks, 2006; Erickson, 2004; Güney, 2005; Isyar, 2005). Kara Ahmet (1994) asserts that the sanction was applied because Turkish security forces had employed weapons against Cyprus, which Ankara had procured from the US. This, according to US authorities, was a violation of the US Foreign Assistance Act of 1961. This particular act bans the usage of US-supplied arms for non-defensive objectives. It is relevant to state here that the Jewish State of Israel has regularly engaged US-supplied ammunition in occupied territories against Palestinians and in Lebanon against unarmed citizens (Ali, 2018; Berrigan, 2009; Sharp, 2008; Twing, 1996), but the American authorities have never enforced such sanctions on Israel. Following the US arms embargo, in 1975 the Turkish authorities took control of all US military posts and air bases within the country previously manned by US military personnel (Khalilzad, 1979-1980). As a result, US economic and security assistance to Turkey remained quite low during these specific years. As per USAID data, between 1974 and 1978, Washington allocated an aggregate of US \$38 million in civilian aid to Ankara (USAID, 2015). In the same way, US security assistance to Turkey also declined sharply from about a billion dollars per annum to about US $\$ 400$ million per year.

\section{Regime Change in Iran and the Soviet Assault on Afghanistan: Rebirth of the US-Turkey Alliance}

The year 1979 witnessed some dramatic shifts in US foreign policy. On the one hand, the US lost its trusted ally, the Shah of Iran in a bloody Islamic revolution that completely alienated Tehran and Washington. On the other hand, the same year the Soviet forces invaded neighboring Afghanistan. The ouster of the Shah from Iran and the attack on Afghanistan by the Soviet Union significantly enhanced the geo-strategic value of Turkey (Ahmad, 2003; Athanassopoulou, 2001; Cook \& Sherwood-Randall, 2006; Erickson, 2004). How to prevent the swelling wave of communist ideology posed a gigantic challenge to several countries in the capitalist bloc. Güney (2005) asserts that the climax of the Cold War-era once again proved that Turkey's distinctive geographical location was one of its prominent assets and it was also a key factor that had elevated the status of Turkey in the eyes of the US policymakers. In view of this, now the US needed the support of Turkey to accomplish its anticommunism goals. As a result, Washington lifted the arms ban and signed the Defence and Economic Cooperation Agreement (DECA) with Ankara in 1980 (Athanassopoulou, 2001; Karaahmet, 1994). After the sanctions were lifted, Turkey also restored the intelligence cooperation work with American authorities, and US security specialists restarted intelligence-gathering vis-à-vis Soviets from the military bases established in this geographically vital country.

It must be recalled that this was the period (1980-83) when Turkey was ruled by a military dictator as was also the case with Pakistan, a key South Asian ally of the US during the Cold War. It was a repressive regime and Ankara's image had been badly tarnished by worsening human rights violations of the military regime. Because of the absence of democratic rule and blatant disregard for human rights, Turkey's relationship with several European countries had worsened (Isyar, 2005). Commenting on the reaction of Europe about the lack of democracy, Robins (2003) asserts that Ankara was under severe criticism from Europe because of the September 1980 army takeover and that the Turkish military junta was under increasing scrutiny because of its punitive actions at the 
domestic front. In contrast to Europe, the stance of the US was quite different as it did not bother about democracy and human rights violations. The US favored a strong government in Ankara as it was critical to protect its security and strategic interests in the region. At the height of the Cold War during these years, the US had 30 bases and security installations where over 5,000 American staff was stationed for the surveillance of the Soviet movements in the region (Karaahmet, 1994). In such circumstances of mutual trust between the US and Turkey, the former was providing generous aid to the latter. According to USAID data, the volume of US economic cooperation increased from US\$ 3 million in 1978 to US\$ 174 million in 1979. It was further increased in the coming years, totaling US\$ 457 million in 1980, US\$ 422 million in 1981, US\$ 592 million in 1982, and US\$ 538 million in the year 1983 (USAID, 2015). The case of US military aid was more or less the same as it also witnessed a consistent upsurge in this period. In view of this, Jacoby (2003) has appropriately observed that at the close of the 1980s, following Israel and Egypt, Turkey emerged as the third leading US aid recipients. In this context, the US-Turkey relations have a similar trajectory as that of the US-Pakistan relations in most of the Cold War period. While Pakistan was also under US sanctions in 1979 because of its not-so-clandestine nuclear program, the Soviet invasion of Afghanistan compelled the US administration to lift sanctions and restart a generous multiyear aid program to its South Asian ally (Ali, 2019a). Hence, like Turkey, Pakistan was also one of the leading recipients of US economic and military assistance as well as a receiver of US arms. The US undoubtedly provided large sums of aid to Turkey and other allies due to their geostrategic significance and to pursue its foreign policy goals related to the containment of communism.

\section{The Gulf Wars: Highs and Lows in US-Turkey Relationship}

After the disintegration of the Soviet Union and the end of the Cold War, Turkey's geopolitical importance decreased for a while. At the same time, there was also a brief period of the end of the honeymoon era in Turkish-US relations. However, the first Gulf War once again proved Turkey's geostrategic significance. It would not have been possible for the US and its allies to successfully conduct military operations without the military and intelligence support provided by Turkey. Hence, Turkey's vital role during the Gulf crisis once again ensured US policymakers who had their acumen, of "Turkey's enduring strategic importance" (Robins, 2003, p. 50). In this context, Ahmad (2003, p. 157) rightly claims that "with the Gulf crisis and the emergence of new Turkic states in Central Asia, Ankara gained a new significance". Turkey declined to send its military to partake in the combat side by side with the coalition forces. Meanwhile, the Turkish government facilitated the US by allowing it to use its airbases in the first Gulf War against a neighboring Muslim country (Hale, 1992). In doing so, it has been argued that "few countries in the region took the security risks that Ankara did" for the support of its allies (Robins, 2003, p. 17). Because of Turkey's contribution to the Gulf crisis, President Bush paid an official visit to Turkey in 1991. The visit aimed to offer his country's gratitude for Turkey's pivotal part in the US-led military campaign against Saddam Hussein. It was the first visit of a US President to Turkey in more than 30 years as Eisenhower was the last president who had traveled to Ankara in 1959 (Athanassopoulou, 2001).

However, Turkey did not offer much assistance to the US and its coalition forces in the Second Gulf War. In October 2003, the matter was brought to the Turkish parliament to decide whether to send its troops to Iraq or not. During the voting, the Turkish parliament voted 358 to 183 to respond positively to the US request for about 10,000 Turkish troops to help contain the rising wave of insurgency in Iraq following the ouster of Saddam (Gunter, 2005). Although the US offered billions of dollars in loans to Turkey, it decided not to send its security forces to Iraq because there was a strong objection from the Iraqi side. As a result of this, the US-Turkey relations also got strained during this particular period because the "United States felt deserted and betrayed by a trusted friend it had long considered a strategically" (Gunter, 2005, p. 120). The same author adds that although Turkey declined to send its troops to Iraq, it allowed US flights more than 4,000 sorties over its territory into Iraq. While the US claimed to bring peace and normalcy to the volatile Middle East, the fact also remains that President Bush was largely perceived to be "in the pocket of the hawkish, pro-Israeli lobby in the United States...more interested in winning votes and avenging his father's failure to oust Saddam Hussein" than in restoring peace and order in the oil-rich Gulf region (Gordon, 2003, p. 155). 


\section{Turkey-US Relations in the War on Terror Period}

In the post-9/11 age of the US global war against terrorism, American foreign policy also underwent some dramatic changes. As regards the role played by Turkey, it presented its air basis for the attack against the Taliban government in Afghanistan. Bacik and Aras (2004) assert that Ankara readily accepted Washington's demands on the use of Turkish territory in the attack against the Taliban regime in Afghanistan. The authors further argue that the Incirlik base in the Mediterranean part of Turkey played a vital role in the US military operations to target key posts of the Taliban fighters in Afghanistan. In addition, being a NATO member, Turkey also sent special security units under the International Security Assistance Force (ISAF) banner to fight Taliban and al-Qaeda (Migdalovitz, 2002). On account of its critical role in the military mission and subsequent reconstruction initiatives, the US provided Turkey US\$ 105 million in security assistance and US\$ 14 million as a part of the International Military Education and Training (IMET) program (Brooks, 2006; Isyar, 2005). Cook and Sherwood-Randall (2006) assert that after the Taliban were ousted from Kabul, Ankara remained a mission of 825 troops in Afghanistan and two times led the NATO International Security Assistance Force there. As a result of its contribution to the Afghan war and supporting US mission in this dangerous battlefield, the US provided considerable military assistance to Turkey.

\section{From Engagement to Estrangement: Divergent Issues in the Current Ties}

In recent years, bilateral ties have considerably deteriorated between the two countries because of several divergent issues. Because of the unabated civil war and instability in neighboring Syria and volatility in Iraq, Turkey has been hosting over 2.5 million refugees from war-ravaged Syria and over 200,000 from Iraq. Turkey criticizes the role of the international community, particularly the US-led coalition forces which are largely responsible for the destruction in these countries. The US and EU countries have not been able to provide sufficient support to Turkey to bear the costs related to hosting such an unprecedented influx of refugees. Not only have this, but attacks on Kurd safe havens in Syria also at times strained bilateral ties between Ankara and Washington. For example, relations between the two countries became quite tense when President Trump wrote a letter to President Erdogan, although there were speculations that Washington itself had quietly given a green signal to Ankara to pound northern Syria when American security forces withdrew from the area and abandoned the Kurdish combatants who had fought alongside the US troops playing a key role in the victory over militants having strong links with the Islamic State. When there was mounting pressure on Trump, his administration issued a dispatch showing a signature of President Trump directed at the Turkish President. The White House provided this letter as solid proof that President Trump was not oblivious to the latest developments taking place on the Syrian battleground. As per his blunt and unorthodox way of addressing domestic as well as international audience, in his October 9, 2019 letter, the US president minced no words and issued clear threats to Turkey to keep a check on its forces stationed in frontlines on the Turkish-Syrian border. The sole superpower of the planet asked Ankara in clear words to stop military incursions inside Syria otherwise these can lead to horrific implications for the economy of Turkey if the US swung into action and imposed sanctions on Ankara. As expected, President Erdogan's ego was profoundly hurt by this affronting US attitude. In a tit for tat reaction, spokespersons in Ankara disclosed to press that the memo from belligerent President Trump was a disgrace to the people of Turkey. They added Turkish president was so angered by that letter that he tossed it in the bin. Besides, the Turkish president lamented that the US president did not care for nuanced diplomacy and that he lacked courteousness in how to address heads of states with dignity (Ali, 2019b). Hence, the overall relations are of course not that much cordial as they used to be in the past.

Another serious issue that has strained relations between Ankara and Washington is the purchase of the Russian S-400 defense system. As this paper has illustrated, Turkey has mostly remained a key US ally and the US has remained the largest arms exporter to Turkey, but recently Turkey has shown interest to get access to the Russian military and defense market. The purchase of a Russian S-400 surface-to-air defense system and its eagerness to acquire Russian fighter aircraft have raised alarm bells in power corridors in Washington. Following the purchase of Russia's S-400 components, "the Trump Administration announced in July 2019 that it was removing Turkey from participation in the F-35 Joint Strike Fighter program" (Zanotti \& Thomas, 2020, p. 6). Hence, there is also the possibility that the US could impose sanctions or some kind of arms embargo on Turkey as it did in the 1970s on the Cyprus issue. 
In addition to the above issues related to the role of Turkey in Syria and the purchase of the latest weapons and defense system from Russia, there is another set of issues that has become contentious between the two countries in recent years. These issues include the Eastern Mediterranean tensions with Greece and Cyprus, evading US sanctions in dealing with Iran, matters regarding democracy and human rights violations, Erdogan's highly critical stance towards Israel and sympathies with Hamas, and the conversion of Hagia Sophia into a mosque (Zanotti \& Thomas, 2020). There has been increasing divergence between the two countries on these matters. The regime of Erdogan has been under the radar of human rights organizations and he has been alleged of undermining democracy and the rule of law by manipulating elections, reining the media, suppressing civil liberties, and targeting his critics and political opponents as well as the Kurdish population and other ethnic and religious minorities (Amnesty International, 2019). Although Turkey has established diplomatic and trade relations with Israel long ago, the Jewish State has been consistently chastised by President Erdogan by highlighting human rights abuses of Israel against Palestinians on various international forums including at the United Nations General Assembly (UNGA), and that Ankara has been tacitly supporting Hamas, a Palestinian group comprising Islamists belonging to Sunni sect of Islam (designated by US authorities as a terrorist organization), are also some of the issues that strain bilateral ties between Turkey and the US (Zanotti \& Thomas, 2020). Besides,

US Secretary of State Mike Pompeo and some other members of the Congress were openly critical of the conduct of the Turkish government when the regime decided in July 2020 to reconvert Istanbul's iconic Hagia Sophia museum into a mosque. It must be mentioned here that the building had been built as a church in the $6^{\text {th }}$ century and was transformed into a mosque during the Ottoman Empire in the $15^{\text {th }}$ century. However, the mosque was designated as a museum in 1934, following Turkey's declaration to become a secular republic. In sum, all these issues have become major points of concern and have caused some kind of estrangement in Turkey-US relations in recent years.

\section{Conclusion}

The paper has explored historical and contemporary US-Turkey bilateral relations covering three distinctive periods comprising the Cold War, the post-Cold War decade of the 1990s, and the era of the war against global terrorism. Because of Turkey's cherished geostrategic position as it is located at the joining center of three regions consisting of the Middle East, Europe, and Asia, and on account of its strong military anchored to the NATO alliance, Turkey has maintained warm bilateral relations with the US for the most of its recent history. If Turkey has played an instrumental role in furthering US security objectives in the region and beyond, it has also received billions of dollars in economic and military assistance as well as arms worth billions of dollars. Whether in the Cold War period to contain communism or the post-Cold War decade and the first Gulf War or again in the war on terror era, Turkey's unique geostrategic location has been its key asset. Because of this, it can also be inferred from the discussion that the geographical and geostrategic significance of a country is largely determined by great powers' politics. Turkey remained at the center of great powers' politics during most of the Cold War period as well as in the Gulf crisis and the war on terror era, hence it was pivotal to safeguard and promote US strategic and security interests in the region and beyond. In the absence of great powers' politics, the same Turkey has little geostrategic significance for the US as the relationship between the two countries has somehow deteriorated in recent years on account of several divergent foreign policy interests. Turkey's rising role in the region and its dispute with Greece on Cyprus and exploration of energy reserves in the Mediterranean has become a major point of concern between Ankara and Washington. Similarly, Turkey has made no secret of its security concerns in Syria to target the Kurdish militia, which once fought alongside US troops against IS militants. And the most critical and thorny issue is related to the purchase of S-400 defense systems from Russia, where the US has hinted of even imposing an arms ban on Ankara if it continued to flirt too much with Moscow. In addition to these, the US has been criticizing the regime of Erdogan and blame it for becoming increasingly authoritarian, violating fundamental human rights and freedom of speech. Because of all these divergent issues, the US-Turkey relationship has grown quite cold in recent years but it does not imply that bilateral ties are at the breaking point.

Acknowledgment: This work was supported by Germany's Alexander von Humboldt (AvH) Foundation in the form of a Return Fellowship under Grant No. 3.5 - 1162883 - PAK - GFHERMESP. 


\section{References}

Ahmad, F. (2003). Turkey: The quest for identity. Oxford, England: Oneworld Publications.

Ali, M. (2018). Aid and Human Rights: the Case of US aid to Israel. Policy Perspectives, 15(3), 29-46.

Ali, M. (2019a). The Politics of US Aid to Pakistan: Aid Allocation and Delivery from Truman to Trump. London and New York: Routledge.

Ali, M. (2019b). Turkey and the US. The News International. Retrieved November 4, 2020, from https://www.thenews.com.pk/print/548497-turkey-and-the-us

Amnesty International. (2019). The State of the World's Human Rights. London: Amnesty International.

Athanassopoulou, E. (2001). American-Turkish relations since the end of the Cold War. Middle East Policy, 8(3), 144-164.

Avci, G. (2005). The postwar incorporation of Turkey into the Western Alliance 1947-1952. European Review, 13(03), 419-429.

Bacik, G., \& Aras, B. (2004). Turkey's inescapable dilemma: America or Europe? Alternatives: Turkish Journal of International Relations, 3(1), 56-74.

Berrigan, F. (2009). Made in the U.S.A.: American military aid to Israel. Journal of Palestine Studies, $38(3), 6-21$.

Bolukbasi, S. (1993). The Johnson letter revisited. Middle Eastern Studies, 29(3), 505-525.

Brooks, K. (2006). A true test of faith in the common defense: US policies toward Turkey. U.S. Army War College, Carlisle.

Brown, C. S. (2008). The one coalition they craved to join: Turkey in the Korean War. Review of International Studies, 34, 89-108.

Cook, S. A., \& Sherwood-Randall, E. (2006). Generating Momentum for a New Era in US-Turkey Relations. Washington: Council on Foreign Relations.

Davison, R. H. (1988). Turkey: A short history (2nd ed.). Huntingdon, England: The Eothen Press.

Erickson, E. (2004). Turkey as regional hegemon--2014: strategic implications for the United States. Turkish Studies, 5(3), 25-45.

Gordon, P. H. (2003). Bush's Middle East Vision. Survival, 45(1), 155-165.

Güney, A. (2005). An Anatomy of the Transformation of the US-Turkish Alliance: From "Cold War" to "War on Iraq". Turkish Studies, 6(3), 341-359.

Gunter, M. M. (2005). The US-Turkish Alliance in Disarray. World Affairs, 167(3), 113-123.

Hale, W. (1992). Turkey, the Middle East, and the Gulf Crisis. International Affairs, 68(4), 679-692.

Henze, P. B. (1993). Turkey: Toward the twenty-first century. In G. E. Fuller, I. O. Lesser, P. B. Henze \& J. F. Brown (Eds.), Turkey's New Geopolitics: From the Balkans to Western China (pp. 1-35). USA: Westview Press.

Isyar, O. G. (2005). Aa Analysis of Turkish-American Relations from 1945 to 2004: Initiatives and Reactions in Turkish Foreign Policy. Alternatives: Turkish Journal of International Relations, 4(3), 21-52.

Jacoby, T. (2003). For the People, Of the People and By the Military: The Regime Structure of Modern Turkey. Political Studies, 51(4), 669-685.

Karaahmet, A. (1994). An Appraisal of US Security Assistance to Turkey Between 1950 and 1992. Naval Postgraduate School, Monterey, California.

Khalilzad, Z. (1979-1980). The Superpowers and the Northern Tier. International Security, 4(3), 6-30.

Migdalovitz, C. (2002). Turkey: Issues for US Policy. Washington: Congressional Research Service.

Robins, P. (2003). Suits and Uniforms: Turkish foreign policy since the Cold War. USA: University of Washington Press.

Sharp, J. M. (2008). U.S. Foreign Aid to Israel. Washington: Congressional Research Service.

SIPRI. (2020). SIPRI Arms Transfers Database. Retrieved November 5, 2020, from https://armstrade.sipri.org/armstrade/page/values.php

Twing, S. L. (1996). The cost of Israel to U.S. taxpayers: a Comprehensive Guide to U.S. Aid to Israel. Washington Report on Middle East Affairs, 14(8), 1-7.

USAID. (2015). US Overseas Loans and Grants (Greenbook). Retrieved December 21, 2015, from http://gbk.eads.usaidallnet.gov/query/do

Vander Lippe, J. M. (2000). Forgotten brigade of the forgotten war: Turkey's participation in the Korean War. Middle Eastern Studies, 36(1), 92-102.

Zanotti, J., \& Thomas, C. (2020). Turkey: Background and U.S. Relations in Brief. Washington, DC: Congressional Research Service. 